\title{
Two administrations of an intravaginal progesterone device on the induction of ovarian cyclicity in anestrous mares
}

\author{
Giovanna Polo', Luis Gustavo Freitag De Limal', Luiz Ernandes Kozicki', Jose Antonio Dell'aqua Junior², Carlos Eduardo Camargo', \\ Márcio Saporski Segui ${ }^{7}$, Rodrigo Macan ${ }^{7}$, Vanessa Alberini ${ }^{7}$, Eduarda Ladewig ${ }^{7}$, Romildo Romualdo Weiss ${ }^{3}$, Melina Andrea Formig- \\ hieri Bertol ${ }^{3}$ and Thalita Capalbo Milleo Polasek'

\footnotetext{
1 Master of Animal Science Graduate, Pontifical Catholic University of Paraná, Agricultural Science and Veterinary Medicine School, Brazil

2 Animal Reproduction Department, State University of São Paulo, UNESP, Bairro Rubião Junior, Botucatu, São Paulo, Brazil

${ }^{3}$ Agricultural Sciences College, Federal University of Parana, Jaime Balão, 575 Curitiba, Paraná, Brazil
}

\begin{abstract}
Summary: The study aimed to evaluate the effect of double administration of a progesterone (P4) intravaginal device on induction of ovarian cyclicity in mares. Twelve crossbred mares were assigned to one of two groups. The first group (GP4; $\mathrm{n}=6 ; 100 \%$ in anestrus phase) underwent the following protocol: day (d) $0,1.9 \mathrm{~g}$ of P4 + ultrasound of the uterus and ovaries (US); d7, US; d 10, first P4 removal + US; d10-d24, US daily; d28, second P4; d35, US; d 40, second P4 removal + US; d 40-d54, US daily; and d54-d76, US every other day. The second group (GNP4; $n=5 ; 100 \%$ in transition phase) underwent the same protocol as GP4, but without the administration of the P4 device. From d 55-d76, 100.0\% of the mares in both groups held uterine tonus and $83.3 \%$ had endometrial edema; after the first and second P4 removal, $66.7 \%$ and $83.3 \%$ of GP4 mares, respectively, reached the transition phase. By d $76,50.0 \%$ and $80.0 \%$ of the GP4 and GNP4 animals, respectively, had ovulated; the average size of the largest follicle increased from d0-d76 in both groups, but was significant only in GP4. Four to five days after the first and second P4 removals in GP4, follicles showed an average growth of $9.0 \mathrm{~mm}$. At the end of the study, both groups had follicular medium diameters greater than $34 \mathrm{~mm}(\mathrm{P}>0.05)$. Ovulations correlated with body condition scores $(\mathrm{P}<0.05)$. In conclusion, two administration of P4 affected ovarian cyclicity in anestrous mares, and synchronized follicular waves and ovulation.
\end{abstract}

Keywords: Progesterone device / Crossbred mares / ovarian cyclicity induction / anestrus / transition phase / reproduction

Citation: Polo G., De Lima L. G. F., Kozicki L. E., Dell'aqua Junior J. A., Camargo C. E., Saporski Segui M., Macan R., Alberini V., Ladewig E., Weiss R. R., Formighieri Bertol M. A., Capalbo Milleo Polasek T. (2016) Two administrations of an intravaginal progesterone device on the induction of ovarian cyclicity in anestrous mares. Pferdeheilkunde 32, 217-222

Correspondence: Prof. Luiz Ernandes Kozicki, Rua Imaculada Conceição 1155, Prado Velho, CEP 80215-901, Curitiba-Paraná, Brazil; e-mail: kozicki.l@pucpr.br

\section{Introduction}

Currently, equine production is a larger component of the Brazilian national economy than it has been in the past, amounting to 5.312 million animals in 2013 (IBGE 2013). Mares are seasonally polyestrous animals that are influenced by photoperiod, with a restricted number of cycles and ovulations throughout the year (Palmer and Guillaume 1992, Guerin and Wang 1994). The anestrus phase is characterized by a relatively relaxed cervix, lack of uterine tonus or endometrial edema, ovaries with follicles $<25 \mathrm{~mm}$, and no corpus luteum (CL) (Newcombe 1994, Newcombe 2002, Handler et al., 2007). Mares carrying follicles smaller than $10 \mathrm{~mm}$ are characterized as being in the deep anestrus phase (Handler et al. 2006). The ultrasonographic characteristics of the uterus (endometrial edema) and follicles (diameter $>35.0 \mathrm{~mm}$ ) help to identify the optimal period for female reproduction (Hayes et al. 1985).

Several protocols, including lighting, hormone programs (e.g., gonadotropin releasing hormone $[\mathrm{GnRH}]$, dopamine antagonists, and recombinant equine follicle stimulating hormone $[\mathrm{FSH}])$, and follicular aspiration, have been used to anticipate the breeding season (McKinnon et al. 1996, Klump et al. 2003, Williams et al. 2012), with the goal of producing early births to allow more time for competition training (Langlois and Blouin 1998, Newcombe 2002). Protocols using progesterone (P4) are distinguished for their ability to synchronize estrus in advance of the breeding season
(Hanlon and Firth 2012). Progesterone may be used in mares in injectable form (IM), per os, subcutaneously, or intravaginally through a device impregnated with P4 Newcombe 2002, Faria and Gradela 2010). Advantages of the intravaginal method are that the device is easy to handle, safe (with the exception of the risk of mild localized vaginitis), and inexpensive (Newcombe 2002). The P4 released by the device suppresses the secretion of luteinizing hormone $(\mathrm{LH})$, levels of which rises quickly when the device is removed, thus stimulating follicular growth and ovulation (Arbeiter et al. 1994, Handler et al. 2007).

The use of intravaginal P4 promotes the advance of the first cover in mares in the transitional phase (Hanlon and Firth 2012). The hormone synchronizes estrus, stimulates ovarian activities, and results in favorable outcomes at any time of the year, except in the anestrus period (Handler et al. 2006).

A protocol based on intravaginal P4 lasting 10 to 12 days was carried out to promote the anticipation of the first mating in acyclic mares (anestrus phase). The study focused on follicular growth under the presence of a dominant follicle (DF), using $\mathrm{GnRH}$ to induce ovulation. The ovulation rate $(\mathrm{OR})$ reached $69.0 \%$ (Arbeiter et al. 1994). Another study in anestrous mares showed similar outcomes (OR was 60,0\%) at 5.3 days post treatment, but there was no difference in pregnancy rate (PR) between cyclic animals and those in anestrus (Newcombe et al. 2002). There were also no differences between $O R$ 
and PR among cyclic and anestrous mares (Arbeiter et al. 1994, Newcombe et al. 2002, Handler et al. 2006).

However, the results of using P4 in anestrous mares are inconsistent. Different responses were observed after its use, which may be due to variation in the anestrus stage of each animal at the beginning of the protocol (Handler et al. 2007). The hypothesis of this study is that the intravaginal P4 administration will induce ovarian cyclicity in mares in anestrus.

This study aimed to evaluate the effects of the two administrations of an intravaginal P4 device on ovarian follicular dynamics in Criollo $\times$ Quarter-Horse anestrous mares.

\section{Materials and methods}

Animals

The study involved 11 crossbred Criollo $\times$ Quarter-Horse mares (Equus caballus), with ages ranging between 4 and 16 years (mean 9.6 \pm 5.3 ), from an experimental farm located at $25^{\circ} 3929 \mathrm{~S}$ and $49^{\circ} 1717 \mathrm{~W}$, Parana, Brazil. The body condition score (BCS) of both groups was $2.9 \pm 0.7$ (=thin, 5 =obese) (Carroll and Huntington 1988). The mares were kept on pasture under natural light, with water, mineral salt, and Tifton hay provided ad libitum. On July 15, during conditions of low sunlight, short days, and the lowest temperatures of the year (average of $12.5^{\circ} \mathrm{C}$ ), the mares commenced the protocol.

\section{Mare selection}

The selection of animals began $15 d$ before the start of the protocol, through daily examinations of the reproductive tract. Only mares free of genital abnormalities were included in the study. Using rectal palpation and ultrasound examinations, uterine tonus, endometrial edema, and the size of ovarian follicles were assessed. The criteria for tonus and endometrial edema (Hayes and Ginther 1986) were as follows: animals with uterine tonus, being either of estrus or diestrus, were considered as having positive tonus (tonus + ); animals with flaccid uterus (anestrus) were considered as having negative tonus (tonus -); and endometrial edema was confirmed by the presence of endometrial swollen folds, as evaluated by ultrasound (edema + ). Animals were assigned to one of two groups. In GP4 $(n=6)$, animals received intravaginal $\mathrm{P} 4$; these mares were in anestrus and had no $\mathrm{CL}$, their follicles were $<25.0 \mathrm{~mm}$ (Handler et al. 2007), and they had poor uterine tonus and no endometrial edema (Newcombe
2002). In GNP4 ( $n=5)$, the mares were not treated (i.e., control treatment) during the transition phase (follicle diameter $\geq 25.0 \mathrm{~mm}$ and luteinization of follicle) (Newcombe 2002). All anestrous mares were assigned to GP4, and therefore GNP4 was composed of the remaining animals, which were in transitional phase. The follicles were measured based on the $[($ smaller diameter $)+$ (larger diameter $)]$ divided by 2 (Gastal et al. 2008). Before the device was inserted, the vulva and perineum were cleaned with mild soap and water, and dried with a paper towel. The device was introduced according to the specifications of the manufacturer (without plastic string) after a spray of hydrochloride oxytetracycline and antiinflammatory (TerraCortril Spray, Pfizer, São Paulo, Brazil). The mares were examined by transrectal ultrasonography (Sonoscape A6, linear transducer frequency $5 \mathrm{MHz}$, China). This project was approved by the ethics committee for the use of animals of the Pontifical Catholic University of Paraná (number 938/2014).

\section{Treatment and examinations}

GP4 was subjected to the following protocol: d0, an intravaginal device with $1.9 \mathrm{~g}$ of $\mathrm{P} 4$ was inserted + ultrasound evaluation (US); d7, US; d10, first P4 removal + US; d10-d24, US daily; d 28, insertion of the second P4 intravaginal device; d35, US; d 40, second P4 removal + US; d 40-d54, US daily; and d 54-d 76, US on alternate days (Figure 1). GNP4 underwent the same protocol as GP4, but without the administration of the intravaginal P4 device.

\section{Statistical analyses}

Data related to quantitative variables were subjected to statistical evaluation using ANOVA and Tukey's test. The qualitative variables were calculated using Fisher's exact test. The Mann-Whitney test was used for BCS comparisons between the groups. The correlation between ovulation and BCS was made using Spearman's test when all animals were used; the Pearson correlation test was used when the groups were analyzed separately. For all analyses, differences were considered statistically significant at the level of $P<0.05$.

\section{Results}

The results of the evaluation of uterine tonus and endometrial edema are shown in Table 1. There were differences between the groups for uterine tonus on $d 0(P=0.015)$. In $G P 4$, there

Fig. 1 Protocol administered to GP4 (= mares receiving the P4 intravaginal device) and GNP4 (= same protocol as GP4, but without the P4 device) over 76 days. Legend: P4 (1.9 g progesterone; CIDR, Pfizer Lab, Sao Paulo.); - P4 = P4 removal; US = ultrasound evaluation

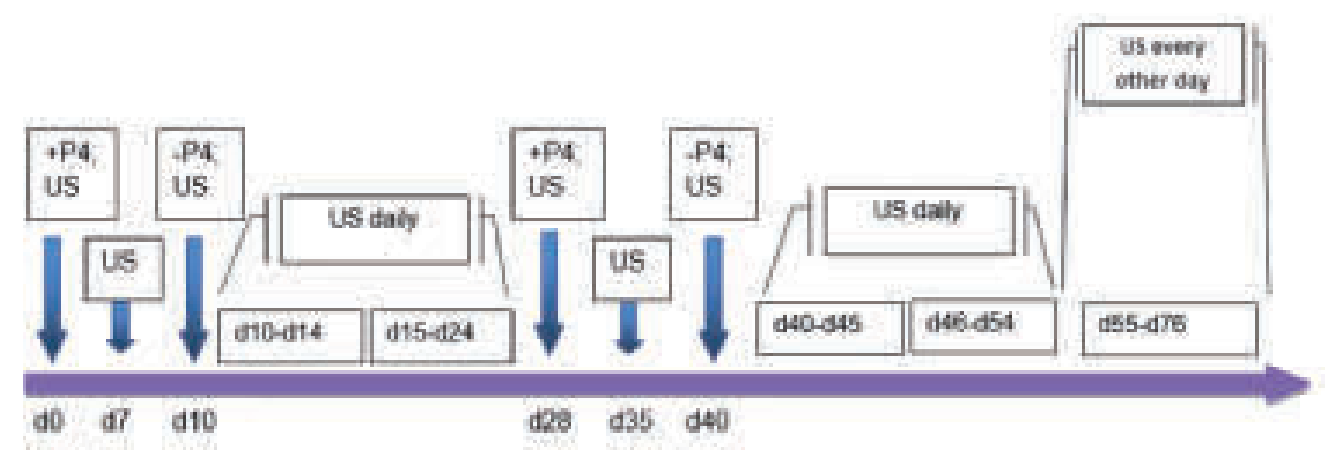


was a significant higher contrast in endometrial edema between the beginning and the end of the study $(P<0.05)$.

In GP4, the diameter of the largest follicle increased after both P4 removals (d 1 1-d 14 and d41-d45; Table 2), and $50 \%$ of the mares ovulated $35.7 \pm 0.6$ days following the removal of the second implant (Figure 2). In GNP4, three follicles luteinized between $\mathrm{d} 7$ and $\mathrm{d} 54$; four ovulations occurred (80.0\%) between $d 55$ and $d 76$.

The size of the largest follicle on $\mathrm{d} 0$ was different between groups ( $P=0.004)$, but at the end of the study (d55-d 76), the difference was no longer present $(P=0.127)$. In GP4, the size of the largest follicle on d 0 was lower from that at the end of treatment $(P<0.05)$ (Table 3$)$. In mares that ovulated between $\mathrm{d} 54-\mathrm{d} 76$, the follicle measured during this period was considered the preovulatory follicle.

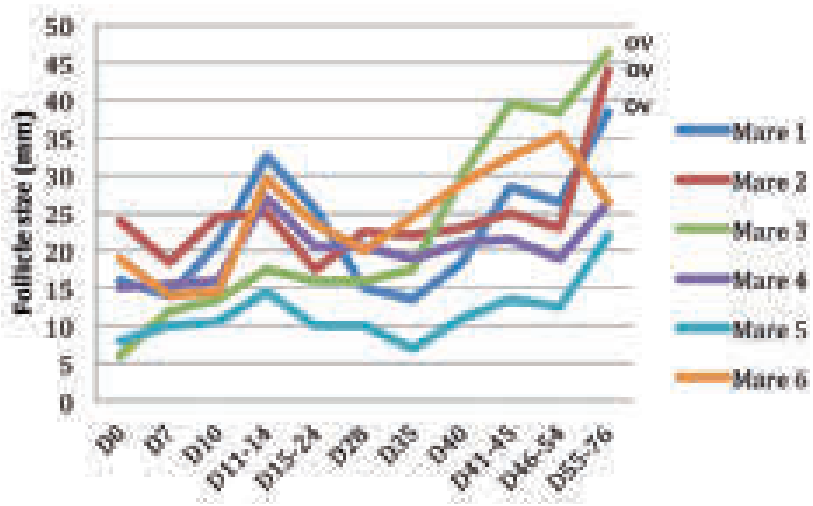

Fig. 2 Size of the largest follicle $(\mathrm{mm})$ in Criollo $\times$ Quarter-horse mares subjected to the intravaginal P4 protocol monitored from $\mathrm{d} 0$ to $\mathrm{d} 76$ by rectal palpation and ultrasound $(n=6)$. Legend: $\mathrm{OV}=$ ovulation.

Table 1 Uterine tonus (UT) and endometrial edema (EE), in Criollo x Quarter Horse mares, receiving $\mathrm{P}_{4}$ (GP4) and control group (GNP4), monitored from $\mathrm{d} 0$ to $\mathrm{d} 76$ by rectal palpation and ultrasound $(\mathrm{n}=11)$

\begin{tabular}{|c|c|c|c|c|c|c|c|c|c|c|c|}
\hline $\begin{array}{l}\text { Days } \\
\text { of protocol }\end{array}$ & do & d7 & $d 10$ & d $11-14$ & d 15-24 & d28 & d35 & $\mathrm{d} 40$ & $\mathrm{~d} 41-45$ & $d 46-54$ & d55-76 \\
\hline $\begin{array}{c}\text { (GP4)UT+ } \\
(\mathrm{n}, \%)\end{array}$ & $\begin{array}{l}0 / 6(0) \\
\mathrm{Bb}\end{array}$ & $\begin{array}{l}6 / 6(100) \\
\mathrm{Aa}\end{array}$ & $\begin{array}{l}6 / 6(100) \\
\mathrm{Aa}\end{array}$ & $\begin{array}{l}6 / 6(100) \\
\mathrm{Aa}\end{array}$ & $\begin{array}{l}6 / 6(100) \\
\mathrm{Aa}\end{array}$ & $\begin{array}{l}6 / 6(100) \\
\mathrm{Aa}\end{array}$ & $\begin{array}{l}6 / 6(100) \\
\mathrm{Aa}\end{array}$ & $\begin{array}{l}6 / 6(100) \\
\mathrm{Aa}\end{array}$ & $\begin{array}{l}6 / 6(100) \\
\mathrm{Aa}\end{array}$ & $\begin{array}{l}6 / 6(100) \\
\mathrm{Aa}\end{array}$ & $\begin{array}{l}6 / 6(100) \\
\mathrm{Aa}\end{array}$ \\
\hline $\begin{array}{c}\text { (GNP4)UT+ } \\
(n, \%)\end{array}$ & $\begin{array}{l}4 / 5(80) \\
\mathrm{Aa}\end{array}$ & $\begin{array}{l}4 / 5(80) \\
\mathrm{Aa}\end{array}$ & $\begin{array}{l}4 / 5(80) \\
\mathrm{Aa}\end{array}$ & $\begin{array}{l}5 / 5(100) \\
\mathrm{Aa}\end{array}$ & $\begin{array}{l}5 / 5(100) \\
\mathrm{Aa}\end{array}$ & $\begin{array}{l}5 / 5(100) \\
\mathrm{Aa}\end{array}$ & $\begin{array}{l}5 / 5(100) \\
\mathrm{Aa}\end{array}$ & $\begin{array}{l}5 / 5(100) \\
\mathrm{Aa}\end{array}$ & $\begin{array}{l}5 / 5(100) \\
\mathrm{Aa}\end{array}$ & $\begin{array}{l}5 / 5(100) \\
\mathrm{Aa}\end{array}$ & $\begin{array}{l}5 / 5(100) \\
\mathrm{Aa}\end{array}$ \\
\hline $\begin{array}{c}\text { (GP4)EE }+ \\
(n, \%)\end{array}$ & $\begin{array}{l}0 / 6(0) \\
\mathrm{Aa}\end{array}$ & $\begin{array}{l}0 / 6(0) \\
\mathrm{Aa}\end{array}$ & $\begin{array}{l}0 / 6(0) \\
\mathrm{Aa}\end{array}$ & $\begin{array}{l}1 / 6(16,7) \\
\text { Aab }\end{array}$ & $\begin{array}{l}2 / 6(33,3) \\
\text { Aab }\end{array}$ & $\begin{array}{l}2 / 6(33,3) \\
\mathrm{Aab}\end{array}$ & $\begin{array}{l}3 / 6(50) \\
\mathrm{Aab}\end{array}$ & $\begin{array}{l}3 / 6(50) \\
\mathrm{Aab}\end{array}$ & $\begin{array}{l}3 / 6(50) \\
\mathrm{Aab}\end{array}$ & $\begin{array}{l}1 / 6(16,7) \\
\text { Aab }\end{array}$ & $\begin{array}{l}5 / 6(83,3) \\
\mathrm{Ab}\end{array}$ \\
\hline $\begin{array}{c}(\mathrm{GNP} 4) \mathrm{EE}+ \\
(\mathrm{n}, \%)\end{array}$ & $\begin{array}{l}3 / 5(60) \\
\text { Aab }\end{array}$ & $\begin{array}{l}0 / 5(0) \\
\mathrm{Aab}\end{array}$ & $\begin{array}{l}0 / 5(0) \\
\mathrm{Aa}\end{array}$ & $\begin{array}{l}2 / 5(40) \\
\text { Aab }\end{array}$ & $\begin{array}{l}3 / 5(60) \\
\mathrm{Aab}\end{array}$ & $\begin{array}{l}4 / 5(80) \\
\mathrm{Ab}\end{array}$ & $\begin{array}{l}2 / 5(40) \\
\mathrm{Aab}\end{array}$ & $\begin{array}{l}2 / 5(40) \\
\text { Aab }\end{array}$ & $\begin{array}{l}0 / 5(0) \\
\mathrm{Aab}\end{array}$ & $\begin{array}{l}0 / 5(0) \\
\mathrm{Aab}\end{array}$ & $\begin{array}{l}4 / 5(80) \\
\mathrm{Ab}\end{array}$ \\
\hline
\end{tabular}

Different capital letters in columns mean statistical difference between groups $(P<0.05)$; Different small letters in lines mean statistical difference within groups $(P<0.05)$.

Table 2 Diameter of the largest follicle $(\mathrm{mm})$, luteinizations/ovulations in Criollo x Quarter Horse mares, receiving $P_{4}(G P 4)$ and control group (GNP4), monitored from $\mathrm{d} 0$ to $\mathrm{d} 76$ by rectal palpation and ultrasound $(\mathrm{n}=11)$

\begin{tabular}{|c|c|c|c|c|c|c|c|c|c|c|c|}
\hline Days & $\mathrm{d} 0$ & $d 7$ & d10 & d11-14 & d15-24 & $\mathrm{d} 28$ & d35 & $\mathrm{d} 40$ & $\mathrm{~d} 41-45$ & $d 46-54$ & d55-76 \\
\hline \multicolumn{12}{|l|}{ GP4 } \\
\hline Mare 1 & 16 & 14 & 21 & 32.5 & 25.5 & 15 & 13.5 & 18.5 & 28.5 & 26.5 & $38.5+\mathrm{OV}$ \\
\hline 2 & 24 & 18.5 & 24.5 & 25 & 17.5 & 22.5 & 22 & 23 & 25 & 23 & $44+\mathrm{OV}$ \\
\hline 3 & 6 & 12 & 13.5 & 17.5 & 16 & 16 & 17.5 & 30 & 39.5 & 38.5 & $46.5+O V$ \\
\hline 4 & 15 & 15.5 & 16 & 27 & 20.5 & 20.5 & 19 & 21 & 21.5 & 19 & 26.5 \\
\hline 5 & 8 & 10 & 10.5 & 14.5 & 10 & 10 & 7 & 11 & 13.5 & 12.5 & 25.5 \\
\hline 6 & 19 & 14 & 14.5 & 29.5 & 23.5 & 20 & 24.5 & 29 & 32.5 & 35.5 & 26.5 \\
\hline \multicolumn{12}{|l|}{ GNP4 } \\
\hline Mare 1 & 25.5 & 23 & 17.5 & 26 & 20 & 20 & 30.5 & 37.5 & 37.5 & 34 & $41+\mathrm{OV}$ \\
\hline 2 & 26.1 & 18.5 & 19 & 26.5 & 26 & 25.5 & 30 & 40 & 26.5 & 25.5 & 39.5 \\
\hline 3 & 26.5 & 30.5 & 33.5 & 47 & 50 & $50+$ LUT & 10.5 & 28 & 24 & 28.5 & $42+\mathrm{OV}$ \\
\hline 4 & 28 & 47+LUT & 10 & 35 & 35.5 & 43.5 & $43.5+$ LUT & 10 & 23.5 & 29.5 & $54+\mathrm{OV}$ \\
\hline 5 & 25.5 & 16.5 & 20 & 16.5 & 20 & 22.5 & 13 & 10 & 12.5 & 15 & $38.5+\mathrm{OV}$ \\
\hline
\end{tabular}

$\mathrm{OV}=$ ovulation; $\mathrm{LUT}=$ luteinization of follicle.

Table 3 Average size of the largest follicle $(\mathrm{mm})$ and ovulations in Criollo x Quarter-horse mares, subjected to $P_{4}$ intravaginal protocol (GP4) and controls (GNP4) checked until d76 ( $\mathrm{n}=11)$

\begin{tabular}{ccccccc}
\hline & $\begin{array}{c}\mathrm{d} 0 \\
\left(1^{\mathrm{s} P 4}\right)\end{array}$ & $\begin{array}{c}\mathrm{d} 11-14 \\
(\mathrm{after} \text { P4 })\end{array}$ & $\begin{array}{c}\mathrm{d} 28 \\
\left(2^{\text {nd }} \mathrm{P} 4\right)\end{array}$ & $\begin{array}{c}\mathrm{d} 41-45 \\
(\text { after P4 })\end{array}$ & $\begin{array}{c}\mathrm{d} 55-76 \\
\text { Ovulation Rate } \\
(\mathrm{n})(\%)\end{array}$ \\
\hline GP4 & $14.7 \pm 6.7^{\mathrm{Ba}}$ & $24.3 \pm 7.0^{\mathrm{Aabc}}$ & $17.3 \pm 4.6^{\mathrm{Bab}}$ & $26.7 \pm 9.0^{\mathrm{Abc}}$ & $34.6 \pm 9.6^{\mathrm{Ac}}$ & $3 / 6(50,0)^{\mathrm{A}}$ \\
GNP4 & $26.3 \pm 1.0^{\mathrm{Aab}}$ & $30.2 \pm 11.5^{\mathrm{Aab}}$ & $32.3 \pm 13.5^{\mathrm{Aab}}$ & $24.8 \pm 8.9^{\mathrm{Aa}}$ & $43.0 \pm 6.3^{\mathrm{Ab}}$ & $4 / 5(80,0)^{\mathrm{A}}$ \\
\hline
\end{tabular}




\begin{tabular}{|c|c|c|c|c|}
\hline Groups & $\begin{array}{c}\text { BCS } \\
(x \pm s)\end{array}$ & $\begin{array}{l}\text { Ovulation Rate } \\
\qquad(\mathrm{n}) ;(\%)\end{array}$ & $\begin{array}{c}\text { Correlation } \\
\text { (r) }\end{array}$ & $\begin{array}{c}\text { Significance } \\
\text { (P) }\end{array}$ \\
\hline GP4 & $2.5 \pm 0.6^{A}$ & $3 / 6(50.0)^{A}$ & 0.866 & 0.025 \\
\hline \multirow[t]{2}{*}{ GNP4 } & $3.3 \pm 0.4^{B}$ & $4 / 5(80.0)^{A}$ & 0.375 & 0.534 \\
\hline & $P=0.051$ & $P=0.55$ & $0.722^{*}$ & $0.012^{*}$ \\
\hline
\end{tabular}

\footnotetext{
Different capital letters in columns mean statistical difference between groups $(\mathrm{P}<0.05)$;

* BCS versus ovulation values in both groups.
}

Ovulations and BCSs are listed in Table 4. BCSs were not statistically different between groups (GP4: $2.5 \pm 0.6$; GNP4: $3.3 \pm 0.4 ; P=0.051)$. There was a significant correlation between ovulation and BCS in GP4 (P=0.0257), but not in GNP4 $(P=0.534)$. A positive correlation was observed $(P=0.012)$ for the comparison of ovulation and BCS in both groups.

\section{Discussion}

Mare reproduction is characterized by its seasonality (i.e., autumn and winter), when the ovaries become inactive (anestrus) and the uterus has low uterine tonus and decreased endometrial edema (Newcombe 2002, Handler et al. 2007). The present study investigated mares in anestrus (GP4), as well as those in the transitional phase (GNP4). Hormonal protocols based on the single use of a P4 intravaginal device have been used for the induction and advancement of the breeding season (Hanlon and Firth 2012). Although some authors have reported satisfactory outcomes in OR (Arbeiter et al. 1994, Newcombe et al. 2002) or induction of cyclicity in anestrous mares with the one-time use of an intravaginal device, other studies do not corroborate these findings (Alexander and Irvine 1991, Handler et al. 2006, Handler et al. 2007). Our hypothesis was that the double insertion of intravaginal P4 could optimize ovarian cyclicity in anestrous mares, even under non-ideal BCS conditions. Fradinho et al. (2014) considered 3.0 the ideal BCS for mares in reproduction. Two intravaginal administration of device in anestrous mares has not been previously reported, which makes this study innovative, and the findings valuable.In the present stu$d y$, intravaginal P4 had a remarkable effect on uterine tonus, which started at $d 7$, after insertion of the device, and persisted throughout the study period. The uterine tonus after the first insertion confirmed the effect of P4 on the uterus (Hayes and Ginther 1986). The endometrial edema was observed after the removal of the first device because of the estrogen from the follicular wave (Hayes and Ginther 1986, Aurich 2011 ), with $50.0 \%$ of the animals having endometrial edema at $\mathrm{d} 35$, and $83.3 \%$ by the conclusion of the study (Table 1). Fifty percent of GP4 showed regression of $\mathrm{LH}$-dependent follicles on $d 7$, probably due to the temporary blocking of $\mathrm{LH}$ caused by the exogenous progesterone (Arbeiter et al. 1994, Handler et al. 2007). The P4 implant initially appeared to stimulate the release of $\mathrm{FSH}$, thereby permitting the maintenance of follicular dynamics, but blocked the final maturation and ovulation of the follicles, which was supposed to occur at the end of the treatment when P4 levels decreased (Arbeiter et al. 1994, Newcombe et al. 2002).

After the first intravaginal device was removed (d 10 and $d 14$ ), $100.0 \%$ of mares from GP4 responded with follicular growth (indicative of the fall in P4 concentration), but without ovulation. Follicle size decreased between $\mathrm{d} 15$ and $\mathrm{d} 24$, resulting in $66.7 \%$ of the mares progressing from the anestrus phase to the transition phase (Table 2, Figure 2). The first effect of the P4 device was sensitizing the mares for ovarian activity, similar to what occurs in beef cattle when P4 is administered before the breeding season (Gümen and Wiltbank 2002). The follicular dynamics became more evident after application of the second P4 device (d28), with all the mares in GP4 having larger follicular diameter at $\mathrm{d} 41-\mathrm{d} 45$ than at $\mathrm{d} 0 ; 50.0 \%$ of mares reached ovulation and $100.0 \%$ had follicles $>25 \mathrm{~mm}$. In contrast, $80.0 \%$ of mares in GNP4 reached ovulation ( $P=0.55$ between GP4 and GNP4) (Table 2).

At the end of the study, the diameter of the largest follicle in GP4 was $>25 \mathrm{~mm}$, demonstrating evident evolution of the cyclic stage Additionally, uterine tonus and endometrial edema were detected in GP4 from d 7 and d 10 onwards, respectively. Based on Newcombe $(1994,2002)$ and Handler et al. (2007), these results indicate that the mares left the anestrus phase. Likewise, another study on anestrous mares corroborates the follicular growth characteristics after P4 removal (Arbeiter et al. 1994).

Thus, our results show that the P4 influenced ovarian activity during this period, and optimized the emergence of new follicular waves (Alexander and Irvine 1991, Arbeiter et al. 1994, Newcombe et al. 2002). In our study, the P4 intravaginal device had a remarkable influence, with the first implant resulting in $66.7 \%$ of mares progressing to the transition phase, and the second implant moving all the remaining animals from the anestrus phase, and inducing synchronized ovulation in $50.0 \%$ of them.

The induction of ovulation in $50.0 \%$ of the GP4 mares was synchronized, as indicated by the fact that two mares ovulated at 35 days and another at 36 days after $\mathrm{P} 4$ removal, and this synchronization is consistent with previously reported findings (Klug and Jöchle 2001). In this case, the ovulations took place in the next follicular wave, increasing the interval between P4 removal and ovulation, but remaining synchronized. The conditions of winter anestrus (monthly average temperature $12.8^{\circ} \mathrm{C}$ ), in conjunction with an average BCS of 2.5 (below ideal), may have influenced the timing of ovarian response to ovulation (Guerin and Wang 1994, Aurich 2011 ).

The failure of some follicles to ovulate in the anestrus phase indicates that other factors may be responsible for the release of ovulatory LH (Newcombe et al. 2002). Mares in anestrus have significantly lower levels of $\mathrm{GnRH}$ and $\mathrm{LH}$ because of the reduced biosynthesis of these hormones during this period. P4 derived from the intravaginal device would not be able to sti- 
mulate the production of these hormones (Handler et al. 2007). In contrast, the use of human chorionic gonadotropin for the induction of ovulation of the DF could be indicated in the wave after P4 removal (Evans et al. 1982, Cole 2010), since the application of $\mathrm{GnRH}$, in order to release $\mathrm{LH}$, is not very effective in anestrous mares (Gentry and Thompson 2002).

Luteinization of follicles is a characteristic of mares in the transitional phase, which usually occurs after anestrus and before the beginning of cyclicity (Newcombe 2002), events that were present in GNP4, but did not occur in GP4.

Comparing the reproductive phases and BCSs between the groups at the beginning, animals were in worse condition (anestrus phase rather than transitional phase and lower average BCS) in GP4 than in GNP4. Even though BCSs were not statistically different $(P=0.051)$, there was a difference in the range (GP4 varied from 1.5 to 3, and GNP4 from 3 to 4)(Table 4). In general, the correlation between the BCS and ovulation was positive $(P=0.012)$. The protocol administered to GP4 was productive for all animals in this group, but since anestrus is also related to nutritional status, only mares that had a BCS $\geq 3$ ovulated (Table 4; Gentry and Thompson 2002). GP4 and GNP4 were kept under the same management and environmental conditions, but GP4 was in the anestrus reproductive phase, while GNP4 was in a more advanced phase (all mares of this group were already in the transition phase with follicles $\geq 25 \mathrm{~mm}$; Table 2). At the end of the study, ovulation rates did not differ between the groups $(P>0.05)$, signaling an acceleration of the breeding season (Hanlon and Firth 2012) in mares treated with P4.

In conclusion, the double administration of the P4 intravaginal device positively influenced the ovarian activity in mares by inducing ovarian cyclicity (or at least the transitional phase), as well as synchronizing their follicular waves and ovulation, even for mares with non-ideal BCSs, leveling the mares to the more advanced group. We recommend double application of intravaginal P4 for reproduction support in anestrous mares.

\section{References}

Alexander S. L. E., Irvine C. H. G. (1991) Control of onset of breeding season in the mare and its artificial regulation by progesterone treatment. J. Reprod. Fertil. Suppl. 44, 307-319

Arbeiter K., Barth U., Jöchle W. (1994) Observations of the use of progesterone intravaginally and of deslorelin STI in acyclic mares for induction of ovulation. Reprod. Rep. 14, 21-25

Aurich C. (2011) Reproductive cycles of horses. Anim. Reprod. Sci. $124,220-228$

Carroll C. L., Huntington P. J. (1988) Body condition scoring and weight estimation of horses. Equine Vet. J. 20, 41-45

Cole L. A. (2010) Biological functions of hCG and hCG-related molecules. Reprod. Biol. Endocrinol. 8, 102

Evans J. W., Roser J. F., Mikuckis G. M. (1982) Comparison of the interaction of equine $\mathrm{LH}$ and human chorionic gonadotropin to equine testicular receptors. J. Reprod. Fertil. 2, 113-121

Faria D. R., Gradela A. (2010) Hormonioterapia aplicada à ginecologia equina. Rev. Bras. Reprod. Anim. 34, 114-122

Fradinho M. J., M.J. Correia M. J., Grácio V., Bliebernicht M., Farrim A., Mateus L., Martin-Rosset W., Bessa R. J. B., Caldeira R. M., Ferreira-Dias G. (2014): Effects of body condition and leptin on the reproductive performance of Lusitano mares on extensive systems. Theriogenology. 81, 1214-1222
Gastal E. L., Neves A. P., Mattos R. C., Petrucci B. P. L., Gastal M. O., Ginther O. J. (2008) Miniature ponies: 1. Follicular, luteal and endometrial dynamics during the oestrous cycle. Reprod. Fertil. Dev. 20, 376-385

Gentry L. R., Thompson Jr. D. L. (2002) The relationship between body condition, leptin, and reproductive and hormonal characteristics of mares during the seasonal anovulatory period. Theriogenology. 58, 563-566

Guerin M. V., Wang X. J. (1994) Environmental temperature has an influence on timing of the first ovulation of seasonal estrus in the mare. Theriogenology. 42, 1053-1060

Gümen A., Wiltbank M. C. (2002) An alteration in the hypothalamic action of estradiol due to lack of progesterone exposure can cause follicular cysts in cattle. Biol. Reprod. 66, 1689-1695

Handler J., Schönlieb S., Hoppen H., Aurich C. (2006) Seasonal effects on attempts to synchronize estrus and ovulation by intravaginal application of progesterone-releasing device (PRIDTM) in mares. Theriogenology. 65, 1145-1158

Handler J., Schönlieb S., Hoppen H., Aurich C. (2007) Influence of reproductive stage at PRIDTM insertion on synchronization of estrus and ovulation in mares. Anim. Reprod. Sci. 97, 382-393

Hanlon D. W., Firth E. C. (2012) The reproductive performance of thoroughbred mares treated with intravaginal progesterone at the start of the breeding season. Theriogenology. 77, 952-958

Hayes K. E. N., Ginther O. J. (1986) Role of progesterone and estrogen in development of uterine tone in mares. Theriogenology. 25, 581-590

Hayes K. E. N., Pierson R. A., Scraba S. T., Ginther O. J. (1985) Effects of estrus cycle and season on ultrasonic uterine anatomy in mares. Theriogenology. 24, 465-477

Instituto Brasileiro de Geografia e Estatística, IBGE (2013) Prod. Pec. munic., Rio de Janeiro. 41, 1-108

Klug E., Jöchle W. (2001) Advances in synchronizing estrus and ovulations in the mare: a mini review. J. Equine Vet. Sci. 21, 474-479

Klump A., Aljarrah A., Sansinena M., Hylan D., Pinto C., Eilts B., Godke R., Paccamonti D. (2003) Follicular aspiration during transition to advance the onset of cyclicity. Pferdeheilkunde 19, 609-610

Langlois B., Blovin C. (1998) Effect of a horse's month of birth on its future sport performance. II. Effect on annual earnings and annual earnings per start. Annales de zootechnie. 47, 67-74

McKinnon A. O., Vasey J. R., Lescun T. B., Trigg T. E. (1996) Repeated use of a GnRH analogue deslorelin (Ovuplant) for hastening ovulation in the transitional mare. Equine Vet. J. 29, 153-155

Newcombe J. R. (1994) Identification of the corpus luteum in non pregnant mares at days 13 to 16 using ultrasound. J. Equine Vet. Sci. 13, 655-656

Newcombe J. R. (2002) Field observations on the use of a progesterone-releasing intravaginal device to induce estrus and ovulation in seasonally anestrous mares. J. Equine Vet. Sci. 22, 378-382

Newcombe J. R., Handler J., Klug E., Meyers P. J., Jöchle W. (2002) Treatment of transition phase mares with progesterone intravaginally and with deslorelin or hcg to assist ovulations. Vet. Rev. 22, 57-64

Palmer E., Guillaume D. (1992) Photoperiodism in the equine species- what is a long night? Anim. Reprod. Sci. 28, 21-30

Williams G.L., Thorson J.F., Prezotto L.D., Velez I.C., Cardoso R. C., Amstalden M. (2012) Reproductive seasonality in the mare: neuroendocrine basis and pharmacologic control. Domest. Anim. Endocrin. 43, 103-115

Erweiterte Zusammenfassung

\section{Wirkungen zweier aufeinanderfolgend intravaginal ein- gesetzter Progesteron-Spiralen zur Induktion des ova- riellen Zyklus bei anöstrischen Stuten}

Stuten sind saisonal polyöstrisch einhergehend mit einer begrenzten Anzahl von Zyklen und Ovulationen. Unterschiedliche Methoden einschließlich der Gabe von Hormonen wer- 